\title{
Mathematical method to find best suited PV technology for different climatic zones of India
}

\author{
Suprava Chakraborty ${ }^{1} \cdot$ Rajesh Kumar $^{1} \cdot$ Avinash Kumar Haldkar $^{1}$. \\ Shishu Ranjan ${ }^{1}$
}

Received: 14 March 2016/Accepted: 28 December 2016/Published online: 7 February 2017

(C) The Author(s) 2017. This article is published with open access at Springerlink.com

\begin{abstract}
This paper presents a reliable mathematical method to predict the energy generation from grid connected photovoltaic plant of different commercially used technologies in different zones of India. Global horizontal insolation (GHI) and daytime temperature are the two major parameters affecting the output of photovoltaic (PV) plant. Depending on those two major parameters, India is classified into 15 climatic zones. Typical Meteorological Year data were collected from National Renewable Energy Laboratory to classify India in different climatic zones. Energy generation of different commercially used PV technologies in different climatic zones of India is predicted using proposed mathematical method. These results show a decisive study to choose the best PV technology for different climatic zones of India. Results predict that in almost all climatic zones, amorphous silicon (a-Si) is the best suitable PV technology. In very low-temperature zones, irrespective of GHI, the second best suitable PV technology is mono and cadmium telluride (CdTe) as generation from these two technologies is same. Whereas in other climatic zones, after a-Si the best suitable is CdTe PV technology. Predicted energy generation is validated with the 1-year generation of 2014 from 15 working PV plants of different technologies. Predicted generation is in good co-relation with the actual real-time generation from the PV plants.
\end{abstract}

Keywords Mathematical method - PV technology · Climatic zone · Energy generation · CUF

Suprava Chakraborty

suprava@ee.ism.ac.in; suprava1008@gmail.com

1 National Institute of Solar Energy, Gurgaon, Haryana 122003, India

\begin{tabular}{|c|c|}
\hline \multicolumn{2}{|c|}{ Abbreviations } \\
\hline GHI & Global horizontal insolation \\
\hline PV & Photovoltaic \\
\hline NREL & National Renewable Energy Laboratory \\
\hline $\mathrm{a}-\mathrm{Si}$ & Amorphous silicon \\
\hline $\mathrm{CdTe}$ & Cadmium telluride \\
\hline CUF & Capacity utilization factor \\
\hline HOMER & $\begin{array}{l}\text { Hybrid optimization model for electric } \\
\text { renewables }\end{array}$ \\
\hline SAM & System advisor model \\
\hline NASA & $\begin{array}{l}\text { National Aeronautics and Space } \\
\text { Administration }\end{array}$ \\
\hline SSE & Surface meteorology and solar energy \\
\hline TMY & Typical Meteorological Year \\
\hline NTPC & National Thermal Power Corporation \\
\hline NVVN & NTPC Vidyut Vyapar Nigam Ltd \\
\hline Mono C-Si & Mono-crystalline silicon \\
\hline Poly C-Si & Poly-crystalline silicon \\
\hline CIGS & Copper indium gallium selenide \\
\hline $\mathrm{P}_{\mathrm{STC}}$ & Power output at STC condition \\
\hline NOCT & Nominal operating cell temperature \\
\hline$I_{\mathrm{t}}$ & Total radiation on a tilted $\mathrm{PV}$ array \\
\hline$I_{\mathrm{b}}$ & $\begin{array}{l}\text { Hourly beam radiation on a horizontal } \\
\text { surface }\end{array}$ \\
\hline$I_{\mathrm{d}}$ & $\begin{array}{l}\text { Hourly diffuse radiation on a horizontal } \\
\text { surface }\end{array}$ \\
\hline$r_{\mathrm{b}}$ & Conversion factors for beam components \\
\hline$r_{\mathrm{d}}$ & Conversion factors for diffuse components \\
\hline$r_{\mathrm{r}}$ & Conversion factors for reflected components \\
\hline$\rho$ & Reflection coefficient of the ground \\
\hline$\theta_{\mathrm{i}}$ & Angle of incidence \\
\hline$\theta_{\mathrm{z}}$ & Zenith angle \\
\hline$\phi$ & Latitude angle \\
\hline$\beta$ & Tilt angle \\
\hline$\gamma$ & Azimuth angle \\
\hline
\end{tabular}


$\delta$

$\omega$

$I_{\mathrm{T}}$

$S_{\mathrm{R}}$

$S_{\mathrm{S}}$

$h_{\text {et }}$

$P_{\text {otc }}$

$P_{\mathrm{m}}$

$T_{\mathrm{a}}$

$T_{\mathrm{STC}}$

$\gamma_{\mathrm{P}}$

$E_{\mathrm{PVP}}$

$D_{\mathrm{f}}$

$H_{\mathrm{f}}$

$W_{1}$

$m_{1}$

$\eta_{\text {inv }}$

PR

$A_{a}$

$\eta_{\text {Panel }}$

JNNSM

LIVLT

LILT

LIMT

LIHT

MIVLT

MILT

MIMT

MIHT

HIVLT

HILT

HIMT

HIHT

VHIMT

VHIHT

VHILT

$\mathrm{MW}_{\mathrm{p}}$

kWh/MW
Solar declination angle

Hour angle

Insolation on tilted surface

Sunrise time

Sunset time

Equivalent hours of full sunshine hours on

tilted surface

Panel output after temperature correction

Power output at STC

Ambient temperature in ${ }^{\circ} \mathrm{C}$

Temperature of the PV module at STC in ${ }^{\circ} \mathrm{C}$

Temperature coefficient of power for PV

panel in $\% /{ }^{\circ} \mathrm{C}$

Energy output from PV plant

Dust factor in \%

Humidity factor in \%

Wiring losses in $\%$

Mismatch losses in \%

Inverter efficiency in $\%$

Performance ratio in $\%$

Active area of panel

Solar panel efficiency in \%

Jawaharlal Nehru National Solar Mission

Low GHI very low temperature

Low GHI low temperature

Low GHI medium temperature

Low GHI high temperature

Medium GHI very low temperature

Medium GHI low temperature

Medium GHI medium temperature

Medium GHI high temperature

High GHI very low temperature

High GHI low temperature

High GHI medium temperature

High GHI high temperature

Very high GHI medium temperature

Very high GHI high temperature

Very high GHI low temperature

Mega Watt peak

Kilo Watt hour/Mega Watt

\section{Introduction}

Interest in forecasting the energy production of PV power plants has increased in recent years from the concern about climate change [1]. Rough estimation of the average energy produced by the PV power plants can be provided through estimation of global irradiance. Goh and Tan [2] developed statistical forecasting of solar data using time series model. Since then number of research work is available on forecasting solar irradiance [3-10]. Theoretically, prediction of global irradiance can be applied to forecast the energy production of PV power plant. The environmental factors influencing the performance of PV module are analyzed in the literature [11-14]. The effect of temperature on the performance of PV modules is analyzed in [15-17]. But, considerably lesser number of literature is present in predicting the actual output of PV power plant.

Some literature is available for estimating field performance of standalone PV array system [18-24]. Also some power efficiency models [25-29] can predict the average performance of a PV system under variable climatic conditions.

Ayompe et al. [29] used different models for PV-cell temperature and models for PV-cell efficiency to predict the accuracy of output power from PV module. The four- and five-parameter models were also investigated [30-34] and compared [35] based on the equivalent circuit of a one-diode model. Considering solar radiation and module temperature, Jones and Underwood [28] proposed a power output model of PV module. Neural networks model is more complicated which uses various inputs such as the solar radiation, ambient temperature, and module temperature [30,31]. The design of neural network model is based on trial and error processes and requires past experience for successful implementation.

Good match between the utility load and the solar resource profile leads to a cost-effective system [29]. Most of the above-mentioned models require either detailed data $[26,30-37]$ and are complicated to use $[35,36]$ or restricted in economic performance evaluation [17-21, 41]. These limitations of the mentioned literature are barrier in easy manipulation of the system performance.

Another problem is that different types of PV technologies respond dissimilarly in the same climatic condition [38]. Santana-Rodríguez et al. [39] concluded that the performance of modules made of amorphous silicon technology is better than other technologies in Mexico City. Ronak et al. [40] observed that performance of amorphous silicon is well under Malaysia's tropical hot and humid climate. Adiyabat et al. [41] showed that a PV module with a high-temperature coefficient, such as crystalline silicon, is advantageous for use in the Gobi Desert area.

Numbers of energy prediction models are available to predict the energy generation of different types of PV modules [42]. Dolara et al. [43] investigated the PV power output prediction using three mathematical models and considered both poly-crystalline and mono-crystalline PV module. Dolara et al. [44] and Leva et al. [45] investigated the $\mathrm{P} V$ power output prediction using neural network and hybrid model. Some of the renowned models used for prediction, design and economic analysis of PV power plant. Hybrid Optimization Model for Electric Renewables (HOMER), RetScreen, System Advisor Model (SAM), PVSyst, PVSol, PVWATT are the most popular PV production model. The first three models 
mentioned can be used for any type of renewable energy resources. Comparing with actual PV plant generation the mentioned models are showing less correlation. Reason behind the poor performance of HOMER and RetScreen models are use of average of 22-year satellite-measured meteorological data up to the year 2002 from National Aeronautics and Space Administration (NASA) renewable energy resource website (Surface Meteorology and Solar Energy). Taking average of 22-year data is not representative of the current weather condition. Typical Meteorological Year (TMY) is the most representative of weather condition for an entire year of a particular location. So TMY data should be used instead of average data. Another drawback is ambient temperature used in all the above-mentioned models is the whole day average temperature whereas only daytime temperature is needed for PV plant energy prediction. SAM model is using TMY file for meteorological parameter; however, its power output prediction is not very close for Indian condition. PVSyst and PVSol both have the ambient temperature issue and PVSol is limited for PV plant using up to 5000 numbers of PV panels only. PVSol is good for rooftop PV plant design where as PVSyst is better in Grid interactive plant. But the economic analysis of PVSyst is not good as per the literature. PVWATT is the latest one and easy model used for energy prediction but that is also not showing the expected accuracy in prediction of energy generation for Indian PV power plants. Therefore, a simple model with adequate precision is desirable for prediction of output from PV power plant based on different PV technology in different climatic zones of India.

The objective of this paper is to present a simple but accurate method for prediction of the energy production from PV plants based on different type of PV technology. This method is applicable to any type of climatic location of India to choose the best suitable technology for that specific location. Establishment of energy demand security needed a bridge between energy schemes and location adjuvant PV technology. Application of the finding of the paper through energy supply planning is helpful to make the energy generation economic and environment friendly. 'Potential map of the location for PV power plants based on different technology and solar resource availability' is effective for selection of PV technology for a particular location. Considering these aspects, the technology explained in this paper suggests the development of a location adjuvant map for solar PV plants which is adjuvant in energy supply planning. The scope of this study is to relate the location and solar energy to study the potential of the location for different types of solar PV plants. Prospective practical users of this method are people from energy industry, energy planners, engineers, city planners, and climate concern citizens.
The research is presented here in four stages. In the next section material and methods used for the research are described, such as collection of data for 300 grid points of India from NREL, manufactures data for different types of PV technologies, etc., followed by which the classification map of India based on global horizontal insolation (GHI) and daytime temperature is presented (till now all available resource maps of India are only based on insolation though temperature is another determining parameter for solar PV technology). In the subsequent section mathematical method for different PV technologies is described to predict the best suitable PV technology for a particular location. Finally, the validation of the method with the realtime energy output of 15 operating PV power plants of different PV technologies under the scheme of National Thermal Power Corporation (NTPC) Vidyut Vyapar Nigam Ltd. (NVVN) for the one whole year of 2014 is presented.

\section{Methodology developed}

Methodology used in this work consists of five different steps. They are concisely discussed as follows:

(a) Division of Indian map in $1^{\circ} \times 1^{\circ}$ grids.

(b) Develop a solar resource map based on global horizontal radiation and daytime average temperature using hourly data of NREL-TMY file. The proposed map can help in selection of location for PV power plant considering two major parameters that affect the output of PV panel.

(c) Classify India zone wise on basis of annual average GHI and day-time temperature.

(d) Selection of commercially used PV technology.

(e) Development of a simple mathematical model with adequate precision for prediction of energy generation from PV power Plant situated at different climatic zones of India.

(f) Collection of location detail, secondary data of energy generation and capacity utilization factor (CUF) of operating PV power plants under the NVVN scheme for the whole year of 2014.

(g) Validation of the developed mathematic model by comparing the predicted energy output with actual PV power plant generated output data under NVNN scheme.

(h) Prediction of the energy generation and CUF of different types of commercially used PV technologies in classified zones of India.

Figure 1a, b depicts the general sketch of the developed methodology and developed energy prediction model, respectively. 
(a)

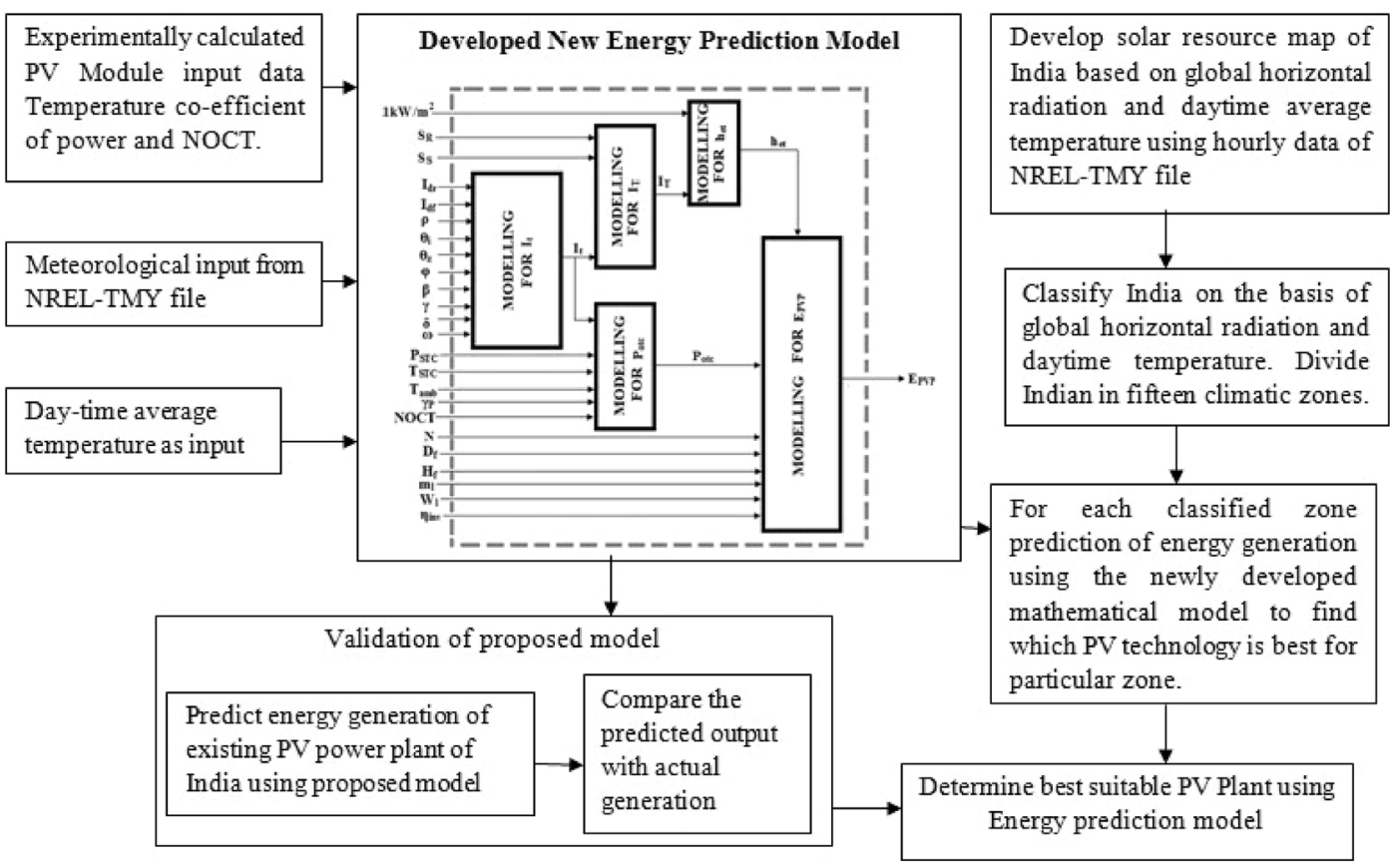

(b)

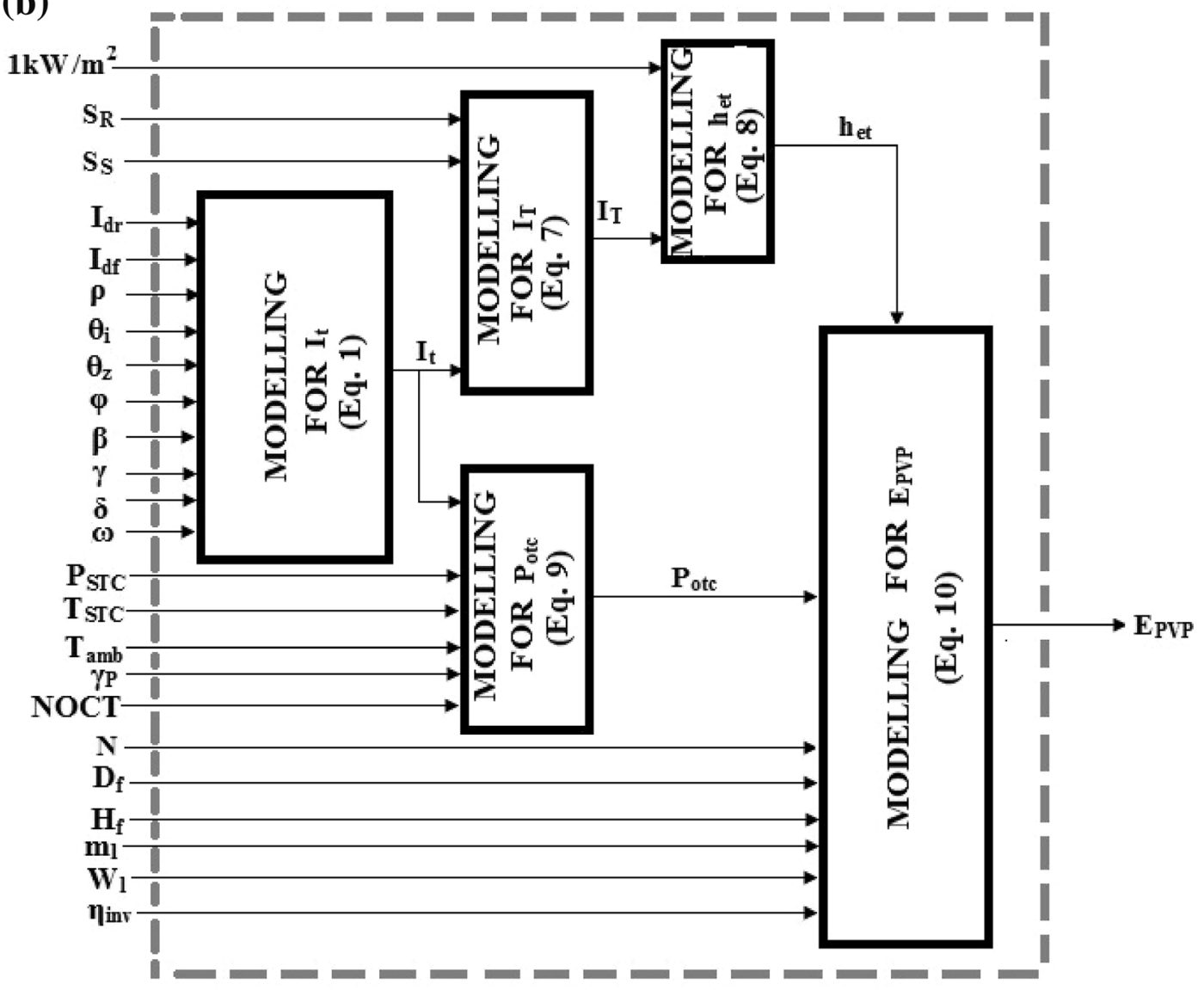

Fig. 1 a General sketch of the developed methodology. b Developed energy prediction model 


\section{Division of Indian map in grids}

Mainland area of 3,287, $263 \mathrm{~km}^{2}$ makes India one of the largest countries in the world. India is equally divided into two halves through the Tropic of Cancer. Pakistan and Burma are situated in the west, China and Nepal in the north to northeastern part and Bhutan in the northeastern part of India. The total length of the land boundary and the shoreline of the country are $15,200 \mathrm{~km}$ and $7517 \mathrm{~km}$, respectively. The boundary of India is wide between $8^{\circ} 4^{\prime}$ and $37^{\circ} 6^{\prime}(\mathrm{N})$ North Latitude and $68^{\circ} 7^{\prime}$ and $97^{\circ} 25^{\prime}($ E) East Longitudes with a measure of 3214 and $2933 \mathrm{~km}$, respectively. Map of India is divided into $1^{\circ} \times 1^{\circ}$ grids. This grid division of India is required for secondary data collection of GHI and temperature from TMY file of NREL. Andaman and Nicobar Islands in the Bay of Bengal and Lakshadweep Islands in Arabian Sea are also part of the Republic of India. But these two islands are not considered in the study as $1^{\circ} \times 1^{\circ}$ grids are large enough for their area. So a separate study for these two locations is needed. Required data for 300 grid points are collected for classification of India on the basis of GHI and day-time temperature. Grid map of India used for data collection is shown in Fig. 2.

Map of India is divided into $1^{\circ}$ grids and magnified grids are also shown in Fig. 2.

\section{Secondary data collection for climatic zone division of India}

GHI and dry bulb temperature for 300 grid points of India are collected from TMY files of NREL website. It is a $10 \times 10 \mathrm{~km}$ resolution data. In TMY, the month that is most representative of the location is selected for consideration. The month for which average radiation is most closely equal to the monthly average over the whole measurement period is representative of the TMY data for that month. This process is then repeated for each month in the year. The months are added together to give a full year of hourly samples. From hourly data of each day average GHI and average daytime temperature of each day is calculated for each grid points. Average of 365 days data is considered to calculate the yearly average GHI and average daytime temperature for each grid points. Hourly data of TMY file is analyzed to get the annual average GHI and only day-time annual average temperature of those grid points. Day-time average temperature is considered to reduce the error in temperature correction. Consideration of overall day temperature instead of only day-time temperature causes overestimation of generation from PV module.

A TMY data set provides designers and other users with a reasonably sized annual dataset that holds hourly

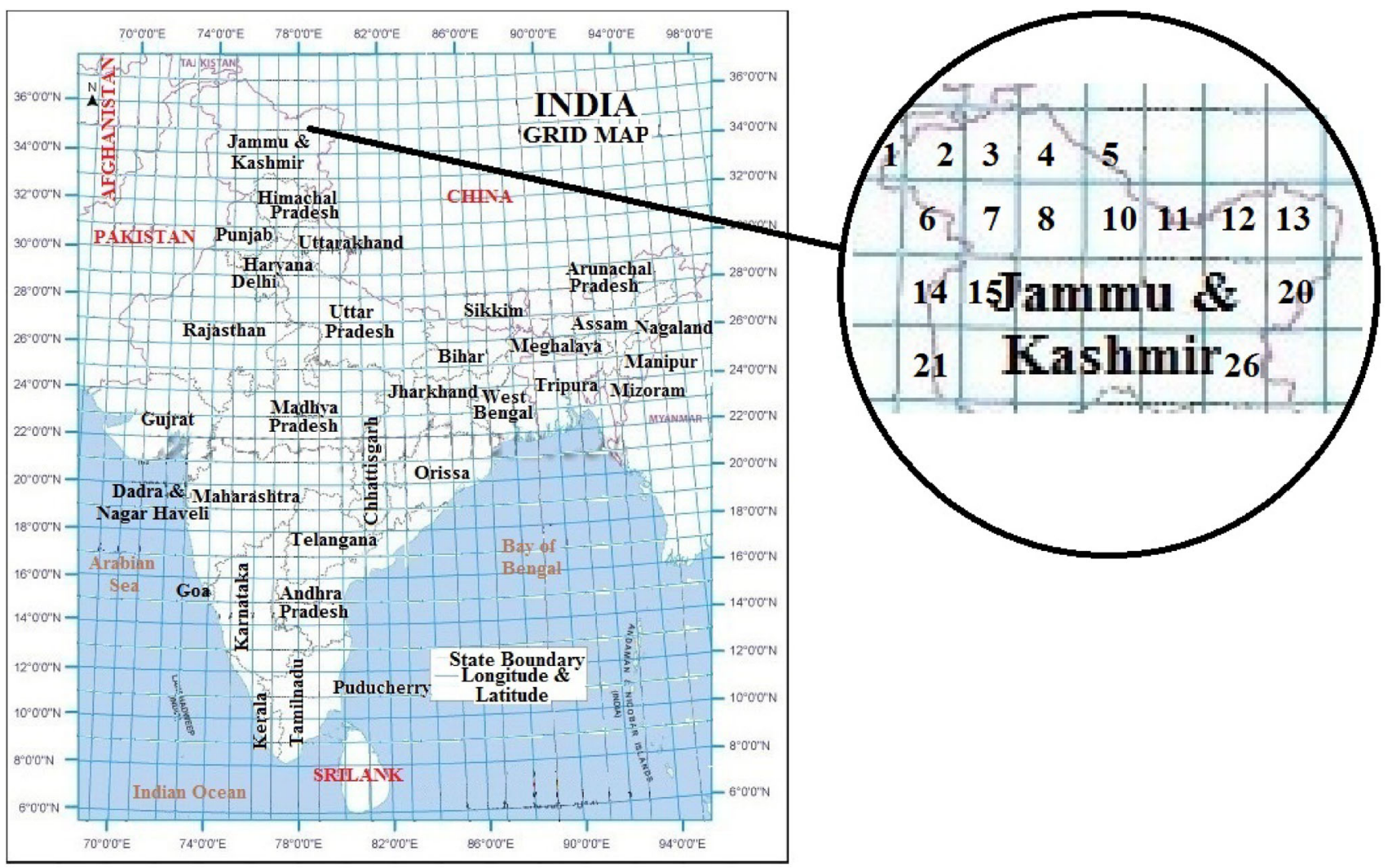

Fig. 2 Grid map of India 
meteorological values that typify conditions at a specific location over a longer period of time, such as 30 years. TMY data have natural diurnal and seasonal variations and represent a year of typical climatic conditions for a location. The TMY data set is composed of 12 typical meteorological months (January through December) that are concatenated essentially without modification to form a single year with a serially complete data record for primary measurements. This method is an empirical approach that selects individual months from different years occurring in the period of record. For example, in the case of the National Solar Radiation Data Base (NSRDB) that contains 30 years of data, all 30 Januarys are examined, and the one judged most typical by the TMY algorithm is selected to be included in the TMY. The other months of the year are treated in a like manner, and then the 12 selected typical months are concatenated to form a complete year. Adjacent months in the TMY may be selected from different years,

Final selection of a month includes consideration of the monthly mean and median and the persistence of weather patterns. The process may be considered a series of steps.

Step 1 For each month of the calendar year, five candidate months with cumulative distribution functions (CDFs) for the daily indices that are closest to the long-term (30 years for the NSRDB) CDFs are selected. The CDF gives the proportion of values that are less than or equal to a specified value of an index.

Step 2 The five candidate months are ranked with respect to closeness of the month to the long-term mean and median.

Step 3 The persistence of mean dry bulb temperature and daily global horizontal radiation are evaluated by determining the frequency and length of runs of consecutive days with values above and below fixed long-term percentiles.

The persistence criteria excludes the month with the longest run, the month with the most runs, and the month with zero runs. The persistence data are used to select from the five candidate months the month to be used in the TMY. The highest ranked candidate month from Step 2 that meets the persistence criteria is used in the TMY.

Step 4 The 12 selected months were concatenated to make a complete year and discontinuities at the month interfaces were smoothed for $6 \mathrm{~h}$ each side using curve fitting techniques.

Only for 10 grid points the analyzed annual average GHI and day-time temperature are shown in Table 1.
Table 1 Annual average GHI and day-time temperature of some grid points of India

\begin{tabular}{llll}
\hline $\begin{array}{l}\text { Grid } \\
\text { no. }\end{array}$ & $\begin{array}{l}\text { Longitude } \\
\text { and latitude }\end{array}$ & $\begin{array}{l}\text { Annual avg. GHI } \\
\mathrm{kWh} / \mathrm{m}^{2} / \mathrm{day}\end{array}$ & $\begin{array}{l}\text { Annual avg. day-time } \\
\text { temperature }\left({ }^{\circ} \mathrm{C}\right)\end{array}$ \\
\hline 1 & $36.5 \mathrm{~N} 74.5 \mathrm{E}$ & 3.72 & -3.06 \\
2 & $36.5 \mathrm{~N} 75.5 \mathrm{E}$ & 4.27 & -6.56 \\
3 & $35.5 \mathrm{~N} 74.5 \mathrm{E}$ & 4.55 & 6.12 \\
4 & $35.5 \mathrm{~N} 75.5 \mathrm{E}$ & 4.28 & 2.74 \\
5 & $35.5 \mathrm{~N} 76.5 \mathrm{E}$ & 4.22 & -7.88 \\
6 & $35.5 \mathrm{~N} 78.5 \mathrm{E}$ & 5.10 & -4.23 \\
7 & $35.5 \mathrm{~N} 79.5 \mathrm{E}$ & 5.38 & -3.16 \\
8 & $34.5 \mathrm{~N} 74.5 \mathrm{E}$ & 4.41 & 11.08 \\
9 & $34.5 \mathrm{~N} 75.5 \mathrm{E}$ & 4.24 & 1.75 \\
10 & $34.5 \mathrm{~N} 76.5 \mathrm{E}$ & 4.93 & 2.85 \\
\hline
\end{tabular}

\section{Selection of PV technology}

Selection of appropriate PV technology is the key for success of any PV power project. In laboratory scale, many new PV technologies are available such as organic solar cell, dye sensitized solar cells, etc., but they are not used commercially for PV power plant. Hence, mono crystalline silicon (Mono C-Si), polycrystalline silicon (Poly C-Si), amorphous silicon (a-Si), CIGS, CdTe PV technologies from reputed manufacturers are considered which are widely used for commercial PV power plant projects. Specifications of the selected PV technologies are collected from their datasheets. Required specifications of the selected PV technologies are enlisted in Table 2.

\section{Mathematical model to predict the energy generation}

Output of PV module is dependent on the meteorological parameters mainly on insolation and ambient temperature. Energy outputs for fixed lilted modules are evaluated zone wise for different technology PV modules. Mathematical modeling is represented below.

\section{Solar radiation on tilted $P V$ array}

Total solar radiation received by PV array which is tilted at a certain angle is known as solar radiation on tilted PV array. In NREL website, the long-term published data of solar radiation and other meteorological parameters are available as hourly average values on horizontal surface for different grid points of India. The solar radiation on a tilted $\mathrm{PV}$ array is the main input parameter for the design of the PV system. According to the Liu and Jordan formula using the hourly beam and diffuse radiation on a horizontal 
Table 2 Technical specifications of selected PV modules

\begin{tabular}{llllll}
\hline PV technology & Manufacturer name & Model no & $P_{\text {STC }}(\mathrm{W})$ & Temp coefficient of power $\left(\% /{ }^{\circ} \mathrm{C}\right)$ & NOCT $\left({ }^{\circ} \mathrm{C}\right)$ \\
\hline Mono-crystalline & Helios Solar & Helios Solar 9T6-420 & 420 & 0.41 & 45 \\
Poly-crystalline & Conergy & PE-300 & 300 & 0.43 & 47 \\
a-Si & Sungen International Limited & SG-HN105-GG & 100 & 0.268 & 40.28 \\
CIGS & Stion & STO-150 & 150 & 0.26 & 45.6 \\
CdTe & First solar & FS-385 & 85 & 0.25 & 45 \\
\hline
\end{tabular}

surface, the total radiation on a tilted PV array (at angle $\beta$ ) for a given latitude $\varphi$ can be evaluated:

$I_{\mathrm{t}}=I_{\mathrm{b}} r_{\mathrm{b}}+I_{\mathrm{d}} r_{\mathrm{d}}+\rho r_{\mathrm{r}}\left(I_{\mathrm{b}}+I_{\mathrm{d}}\right)$

$I_{\mathrm{b}}$ is the hourly beam radiation on a horizontal surface; $I_{\mathrm{d}}$ hourly diffuse radiation on a horizontal surface; $r_{\mathrm{b}}, r_{\mathrm{d}}$ and $r_{\mathrm{r}}$ are known as conversion factors for beam, diffuse and reflected components, respectively; $\rho$ is the reflection coefficient of the ground $(0.2$ and 0.6 for non-snow-covered and snow-covered ground, respectively).

$r_{\mathrm{b}}=\frac{\operatorname{Cos} \theta_{i}}{\operatorname{Cos} \theta_{z}}$

$r_{\mathrm{d}}=\frac{1+\operatorname{Cos} \beta}{2}$

$r_{\mathrm{r}}=\frac{1-\operatorname{Cos} \beta}{2}$

$\operatorname{Cos} \theta_{\mathrm{i}}=(\operatorname{Cos} \phi \operatorname{Cos} \beta+\operatorname{Sin} \phi \operatorname{Sin} \beta \operatorname{Cos} \gamma) \operatorname{Cos} \delta \operatorname{Cos} \omega$ $+\operatorname{Cos} \delta \operatorname{Sin} \omega \operatorname{Sin} \beta \operatorname{Sin} \gamma+(\operatorname{Sin} \phi \operatorname{Cos} \beta$

$-\operatorname{Cos} \phi \operatorname{Sin} \beta \operatorname{Cos} \gamma) \operatorname{Sin} \delta$

$\operatorname{Cos} \theta_{\mathrm{z}}=\operatorname{Cos} \phi \operatorname{Cos} \delta \operatorname{Cos} \omega+\operatorname{Sin} \phi \operatorname{Sin} \delta$

$\theta_{\mathrm{i}}$ is angle of incidence, $\theta_{\mathrm{z}}$ zenith angle; $\phi$ the latitude angle; $\beta$ the tilt angle; $\gamma$ the azimuth angle; $\delta$ the solar declination angle; $\omega$ is the hour angle.

Insolation on tilted surface, $\quad I_{\mathrm{T}}=\int_{S_{\mathrm{R}}}^{S_{\mathrm{S}}} I_{\mathrm{t}}$

$S_{\mathrm{R}}$ is the sunrise time; $S_{\mathrm{S}}$ is the sunset time.

Daily PV array output is the summation of the hourly energy output.

\section{Equivalent full sun-shine hours on tilted surface}

No. of hours for which the intensity of solar radiation incident at a place is kept constant at its peak value of $1 \mathrm{~kW} / \mathrm{m}^{2}$ is known as equivalent hours of full sunshine $\left(h_{\mathrm{et}}\right)$. When insolation on tilted unit area surface is expressed by $I_{\mathrm{T}} \mathrm{kWh} / \mathrm{m}^{2} /$ day, then it can be expressed as constant peak value of solar radiation of $1 \mathrm{~kW} / \mathrm{m}^{2}$ incident on a receiving surface for $I_{T} \mathrm{~h}$, then $h_{\mathrm{et}}$ will be equal to $I_{\mathrm{T}} \mathrm{h} /$ day. The expression is given by Eq. (7)
$h_{\mathrm{et}}=\frac{I_{\mathrm{T}}}{1 \mathrm{~kW} / \mathrm{m}^{2}}$

$h_{\text {et }}$ is the equivalent full sun-shine hours on tilted surface; $I_{\mathrm{T}}$ is Insolation on tilted surface in $\mathrm{kWh} / \mathrm{m}^{2} /$ day.

\section{PV panel output after temperature correction}

Power output of PV panel after consideration of reduction in power output from PV panel due to deviation of its temperature from $25^{\circ} \mathrm{C}$ is known as PV panel output after temperature correction. The output of $\mathrm{PV}$ module is dependent on solar radiation and the operating temperature of PV module. Rise in the PV operating temperature with respect to STC condition, reduces the energy output from PV module. Operating temperature of PV module can be calculated by means of ambient temperature, incident solar irradiance on PV module at given location and Nominal Operating Cell Temperature (NOCT) of the particular technology [46-49].

$P_{\text {otc }}=P_{\mathrm{m}}\left[1-\left\{T_{\mathrm{a}}+\left(\frac{(\mathrm{NOCT}-20)}{800} \times I_{\mathrm{t}}\right)-T_{\mathrm{STC}}\right\} \times \gamma_{\mathrm{P}}\right]$

$P_{\text {otc }}$ is the panel output after temperature correction; $P_{\mathrm{m}}$ the power output at STC; $T_{\mathrm{a}}$ the ambient temperature in ${ }^{\circ} \mathrm{C}$; NOCT the nominal operating cell temperature; $I_{\mathrm{t}}$ the irradiance in $\mathrm{W} / \mathrm{m}^{2} ; T_{\mathrm{STC}}$ the temperature of the PV module at STC in ${ }^{\circ} \mathrm{C} ; \gamma_{\mathrm{P}}$ is the temperature coefficient of power for $\mathrm{PV}$ panel in $\%{ }^{\circ} \mathrm{C}$.

\section{Generated energy from PV plant feed to the grid}

Total generated energy from PV array that is fed to the electricity grid is known as generated energy from PV plant feed to the grid.

$$
\begin{aligned}
E_{\mathrm{PVP}}= & P_{\mathrm{otc}} \times h_{\mathrm{et}} \times\left(1-D_{\mathrm{f}}\right)\left(1-H_{\mathrm{f}}\right)\left(1-W_{\mathrm{l}}\right)\left(1-m_{\mathrm{l}}\right) \\
& \times \eta_{\text {inv }}
\end{aligned}
$$

$E_{\mathrm{PVP}}$ is the energy output from PV plant; $D_{\mathrm{f}}$ the dust factor in $\% ; H_{\mathrm{f}}$ the humidity factor in $\% ; W_{1}$ the wiring losses in 
$\%$; $m_{1}$ the mismatch losses in $\%, \eta_{\text {inv }}$ is the inverter efficiency in $\%$.

\section{Performance ratio}

Performance ratio is defined as the ratio of the array yield to the reference yield. Array yield is defined as the total energy generated by the PV array for a defined period divided by the rated output power of the installed PV array. Reference yield is defined as the ratio of total in plane solar insolation to the reference irradiance. Array yield and the reference yield both are time-dependent parameters. The performance ratio (PR) is a system performance index that indicates the overall effect of losses on the array's rated output due to array temperature, incomplete utilization of the irradiation, and system component inefficiencies or failures (IEC 61724).

$\mathrm{PR}=\frac{E_{\mathrm{PVP}}}{A_{\mathrm{a}} \times I_{\mathrm{T}} \times \eta_{\text {Panel }}} \times 100$

$\mathrm{PR}$ is the performance ratio in $\% ; A_{\mathrm{a}}$ the active area of panel; $\eta_{\text {Panel }}$ is the solar panel efficiency in $\%$.
Energy yield factor

Energy yield factor (YF) of the PV system defined as the portion of the daily net energy output of the entire PV plant which is supplied by the array per $\mathrm{kW}$ of installed PV array.

$\mathrm{YF}=\frac{E_{\mathrm{PVP}}}{P_{\mathrm{m}}}$

YF is the yield factor.

\section{Capacity utilization factor}

Practical output of a power plant over a period of time divided by its potential output of power plant if had operated at full nameplate capacity for the entire time is known as net capacity utilization factor (CUF) of that power plant. To calculate the CUF, the sum of energy production in a particular period considered and divides by the amount of energy the plant actually capable of produce at its full capacity.

Table 3 Details of some PV plants in India

\begin{tabular}{|c|c|c|c|c|}
\hline Bidder name & $\begin{array}{l}\text { Capacity } \\
\text { in MW }\end{array}$ & Location & $\begin{array}{l}\text { Latitude and } \\
\text { longitude }\end{array}$ & Technology \\
\hline Comet Power Pvt. Ltd. & 5 & $\begin{array}{l}\text { Village-Bham Bhuo Ki Dhani, Tehsil-Osiyan, } \\
\text { Dist._Jodhpur, Rajasthan. }\end{array}$ & $\begin{array}{l}26^{\circ} 44^{\prime} 37.32^{\prime \prime} \mathrm{N} \\
72^{\circ} 58^{\prime} 56.28^{\prime \prime} \mathrm{E}\end{array}$ & Poly C-Si \\
\hline Videocon Industries Ltd, Mumbai & 5 & Taluka: Warora, Dist.—Chandrapur, Maharashtra. & $\begin{array}{l}20^{\circ} 18^{\prime} 8.64^{\prime \prime} \mathrm{N}, 79^{\circ} \\
01^{\prime} 9.60^{\prime \prime} \mathrm{E}\end{array}$ & Poly C-Si \\
\hline $\begin{array}{l}\text { Mahindra Suryaprakash Private } \\
\text { Limited }\end{array}$ & 20 & $\begin{array}{l}\text { Village-Rawra, Tehsil Phalodi, Distt.—Jodhpur, } \\
\text { Rajasthan. }\end{array}$ & $\begin{array}{l}27^{\circ} 23^{\prime} 44.38^{\prime \prime} \mathrm{N}, 72^{\circ} \\
09^{\prime} 14.78^{\prime \prime} \mathrm{E}\end{array}$ & Thin film \\
\hline $\begin{array}{l}\text { Mahindra Suryaprakash Private } \\
\text { Limited }\end{array}$ & 10 & $\begin{array}{l}\text { Village-Rawra, Tehsil Phalodi, Distt._-Jodhpur, } \\
\text { Rajasthan. }\end{array}$ & $\begin{array}{l}27^{\circ} 23^{\prime} 44.38^{\prime \prime} \mathrm{N}, 72^{\circ} \\
09^{\prime} 14.78^{\prime \prime} \mathrm{E}\end{array}$ & Thin film \\
\hline $\begin{array}{l}\text { NVR Infrastructure And Services } \\
\text { Private Limited }\end{array}$ & 10 & $\begin{array}{l}\text { Village-Kisnayat Buddan, Tehsil Kolayat, } \\
\text { Distt.Bikaner, Rajasthan. }\end{array}$ & $27.83^{\circ} \mathrm{N}, 72.95^{\circ} \mathrm{E}$ & $\begin{array}{l}\text { Poly C-Si and } \\
\text { thin film }\end{array}$ \\
\hline $\begin{array}{l}\text { Sai Mathili Power Company } \\
\text { Private Limited }\end{array}$ & 10 & $\begin{array}{l}\text { Village-Gurha, Tehsil Kolayat, Distt.-Bikaner, } \\
\text { Rajasthan. }\end{array}$ & $\begin{array}{l}27^{\circ} 51^{\prime} 50^{\prime \prime} \mathrm{N} \\
72^{\circ} 50^{\prime} 20^{\prime \prime} \mathrm{E}\end{array}$ & CIGS \\
\hline
\end{tabular}

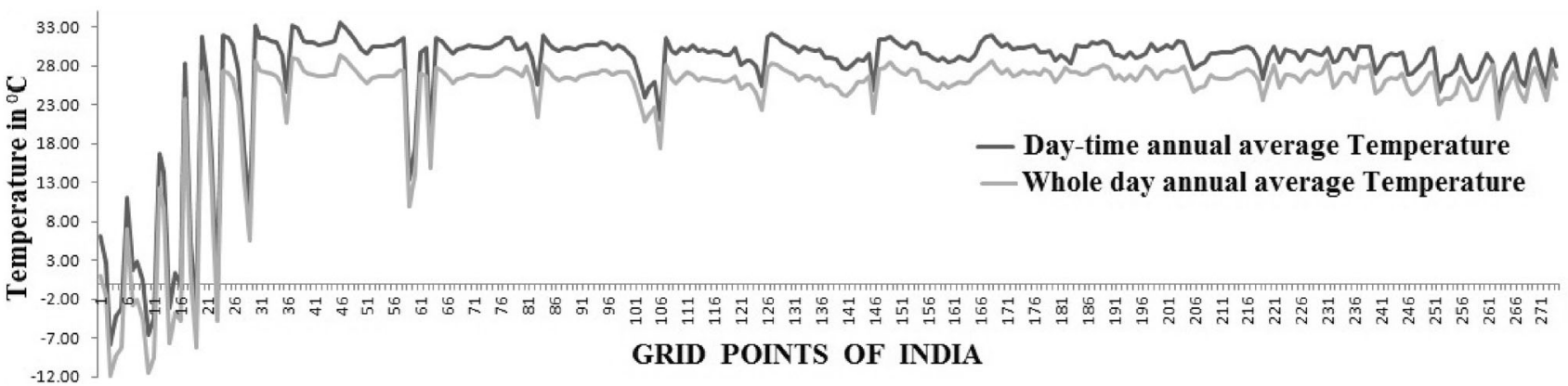

Fig. 3 Day-time and whole day annual average temperature for 300 grid points of India. Maximum $5.16{ }^{\circ} \mathrm{C}$ temperature difference is observed between these two temperatures 


\section{Collected data of solar PV projects in India}

Under the scheme of Jawaharlal Nehru National Solar Mission (JNNSM) numbers of Solar PV plants are already installed in India and many other are going to be installed to fulfill the target of JNNSM. For successful execution of JNNSM, NTPC Vidyut Vyapar Nigam Ltd (NVVN) [50] has given the responsibility to prepare the guidelines for selection of developers for commissioning grid connected solar power projects in India. Location and monthly field measured generation data of fifteen existing PV plants of different technologies for one whole year of 2014 in India are collected from the project installer [50]. Some of the PV plants details are tabulated in Table 3.

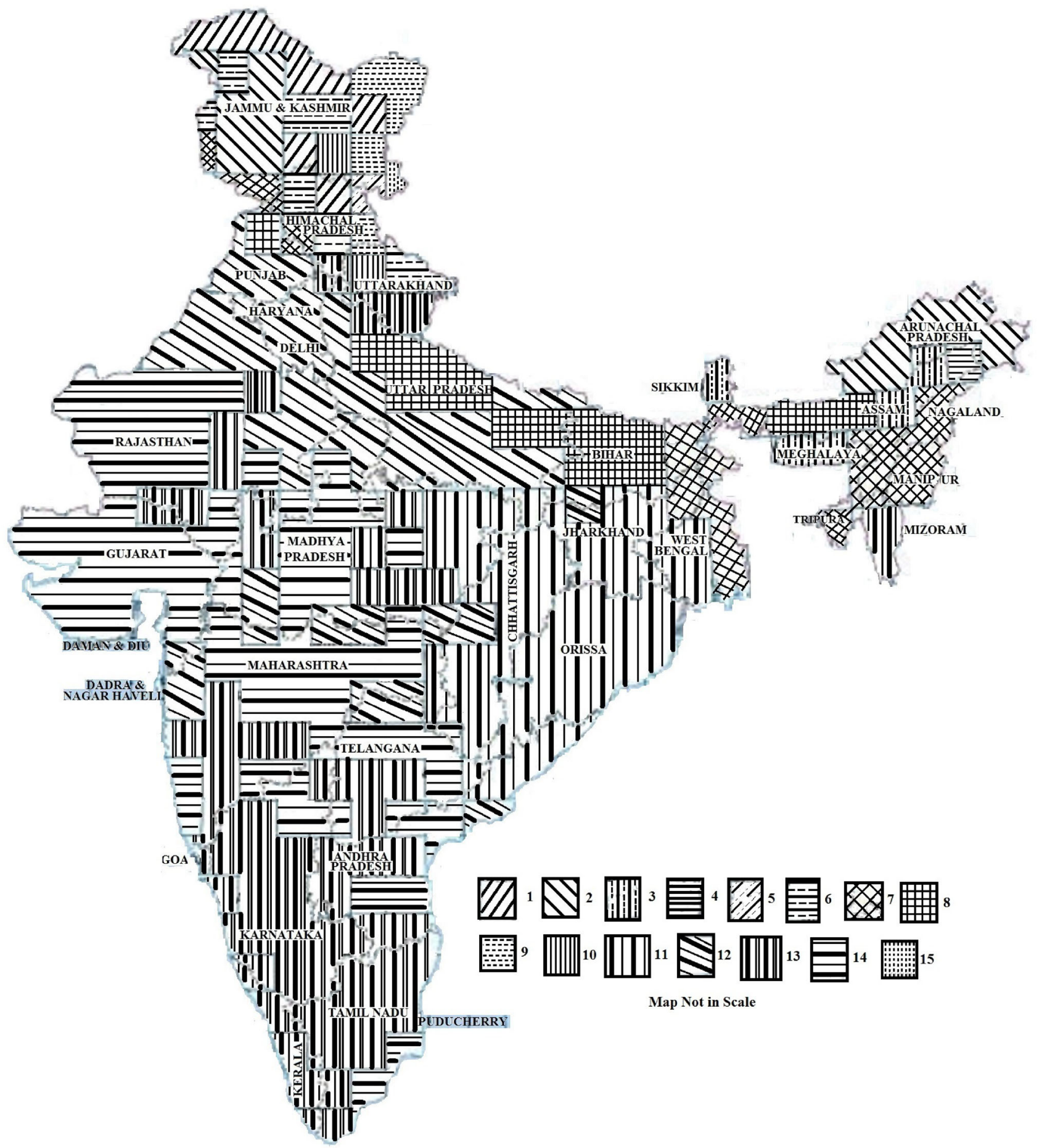

Fig. 4 Classification of India on the basis of annual average GHI and day-time temperature 
Table 4 Name of the climatic zones

\begin{tabular}{lll}
\hline Climatic zones & GHI & Day-time Temperature \\
\hline 1. Low GHI very low temperature (LIVLT) & $<4.5 \mathrm{kWh} / \mathrm{m}^{2} / \mathrm{day}$ & $<0{ }^{\circ} \mathrm{C}$ \\
2. Low GHI low temperature (LILT) & & $0-20{ }^{\circ} \mathrm{C}$ \\
3. Low GHI medium temperature (LIMT) & $20-30{ }^{\circ} \mathrm{C}$ \\
4. Low GHI high temperature (LIHT) & $\geq 30{ }^{\circ} \mathrm{C}$ \\
5.Medium GHI very low temperature (MIVLT) & $4.5-5 \mathrm{kWh} / \mathrm{m}^{2} /$ day & $<0{ }^{\circ} \mathrm{C}$ \\
6. Medium GHI low temperature (MILT) & & $0-20{ }^{\circ} \mathrm{C}$ \\
7. Medium GHI medium temperature (MIMT) & & $20-30{ }^{\circ} \mathrm{C}$ \\
8. Medium GHI high temperature (MIHT) & & $\geq 30{ }^{\circ} \mathrm{C}$ \\
9. High GHI very low temperature (HIVLT) & $5-5.5 \mathrm{kWh} / \mathrm{m}^{2} / \mathrm{day}$ & $<0{ }^{\circ} \mathrm{C}$ \\
10. High GHI low temperature (HILT) & & $0-20{ }^{\circ} \mathrm{C}$ \\
11. High GHI medium temperature (HIMT) & & $20-30{ }^{\circ} \mathrm{C}$ \\
12. High GHI high temperature (HIHT) & $\geq 30{ }^{\circ} \mathrm{C}$ \\
13. Very high GHI medium temperature (VHIMT) & $\geq 5.5 \mathrm{kWh} / \mathrm{m}^{2} /$ day & $20-30{ }^{\circ} \mathrm{C}$ \\
14. Very high GHI high temperature (VHIHT) & & $\geq 30{ }^{\circ} \mathrm{C}$ \\
15. Very high GHI low temperature (VHILT) & & $0-20{ }^{\circ} \mathrm{C}$ \\
\hline
\end{tabular}

\section{Results and discussion}

Results and discussion part is sub-divided into three parts. (1) Classification of India in different climatic zones considering on GHI and day-time temperature. (2) Prediction of energy output and CUF from different PV technologies in different climatic zones of India using mathematical method. (3) Validation of the mathematical method with practical field output data of $15 \mathrm{PV}$ plants of different technologies.

\section{Classification of India in different climatic zones}

To know the energy output from different photovoltaic technologies in different zones of India, first step is to classify India in different climatic zones on the basis of annual average GHI and day-time temperature, the major two factors affecting the output of PV technology. Indian map is divided into grids by its longitude and latitude. For each degree apart one point is selected as grid point. Thus, 300 grid points have been selected. Secondary data of TMY file from NREL website [30] are collected for those 300 grid points to classify India in 15 climatic zones depending on annual average GHI and day-time average temperature. For 300 grid points daytime and whole day annual average temperature is also calculated to know the difference between these two temperatures. This temperature difference causes error in most of the prediction techniques as whole day average temperature is considered in most of the PV output predicting softwares, such as RetScreen and Homer. Figure 3 shows the daytime and whole day average temperature for the selected grid points.
Classification of India in different climatic zones depending on GHI and day-time average temperature is presented in Fig. 4.

\section{Energy output (kWh) of different PV technologies in different climatic zones of India}

Annual average energy output and CUF of $1 \mathrm{MW}_{\mathrm{p}}$ power plant of different technologies in different climatic zones is calculated using 2.4.4 and 2.4.7. All the related data like temperature coefficient of power and NOCT value for different PV technologies are used from the data sheets of manufacturers to calculate the energy output.

It is seen that in all climatic zones energy generation and CUF is maximum for $1 \mathrm{MW}$ a-Si $\mathrm{PV}$ power plant (Tables 5, 6).

\section{Validation of the mathematical method}

Depending on the availability of actual field data 15 PV power plants are selected. It is found that all the 15 selected PV power plants of different technologies are situated in the same climatic zone, i.e., Zone 14 (very high GHI high temperature). Among the selected $15 \mathrm{PV}$ power plants, plant 1-9 is based on Multi C-Si, 10 is of a-Si, 11-13 is based on CdTe technology and 14-15 is based on CIS technology. For validation of the mathematical method actual field output of PV plants are compared with the predicted value. 15 different PV power plants are of different capacity, so exported energy of the PV power plants are normalized to $1 \mathrm{MW}$ power plant. Validation table is presented in Table 6. 
Table 5 Annual average energy output range and CUF at different climatic zones of India for different PV technologies

\begin{tabular}{|c|c|c|c|c|}
\hline \multirow[t]{2}{*}{ Type of cell } & \multicolumn{2}{|l|}{ Zone 1} & \multicolumn{2}{|l|}{ Zone 2} \\
\hline & Yearly generation (kWh) & Average CUF & Yearly generation $(\mathrm{kWh})$ & Average CUF \\
\hline \multicolumn{5}{|l|}{ Zone- 1 and 2} \\
\hline Mono C-Si & $1,469,873.24-1,865,416.1$ & 19.04 & $1,363,573.18-1,698,380.38$ & 17.48 \\
\hline Poly C-Si & $1,457,232.33-1,849,373.52$ & 18.87 & $1,351,846.45-1,675,069.28$ & 17.28 \\
\hline $\mathrm{a}-\mathrm{Si}$ & $1,488,466.55-1,889,012.86$ & 19.28 & $1,380,821.84-1,774,325.73$ & 18.01 \\
\hline CIGS & $1,467,580.24-1,862,506.05$ & 19.01 & $1,361,446.01-1,750,996.87$ & 17.77 \\
\hline CdTe & $1,469,873.24-1,865,416.1$ & 19.04 & $1,363,573.182-1,757,583.18$ & 17.81 \\
\hline \multirow[t]{2}{*}{ Type of cell } & \multicolumn{2}{|l|}{ Zone 3} & \multicolumn{2}{|l|}{ Zone 4} \\
\hline & Yearly generation (kWh) & Average CUF & Yearly generation (kWh) & Average CUF \\
\hline \multicolumn{5}{|l|}{ Zone- 3 and 4} \\
\hline Mono C-Si & $1,437,138.15-1,482,542.94$ & 16.66 & $1,482,543$ & 16.92 \\
\hline Poly C-Si & $1,417,412.73-1,457,862.07$ & 16.41 & $1,457,862$ & 16.64 \\
\hline $\mathrm{a}-\mathrm{Si}$ & $1,501,401.71-1,575,940.78$ & 17.56 & $1,575,941$ & 17.99 \\
\hline CIGS & $1,481,661.26-1,555,976.99$ & 17.34 & $1,555,977$ & 17.76 \\
\hline CdTe & $1,487,234.47-1,563,685.54$ & 17.41 & $1,563,686$ & 17.85 \\
\hline \multirow[t]{2}{*}{ Type of cell } & \multicolumn{2}{|l|}{ Zone 5} & \multicolumn{2}{|l|}{ Zone 6} \\
\hline & Yearly generation (kWh) & Average CUF & Yearly generation $(\mathrm{kWh})$ & Average CUF \\
\hline \multicolumn{5}{|l|}{ Zone-5 and 6} \\
\hline Mono C-Si & $1,778,776.55-1,976,714.59$ & 21.44 & $1,740,455.21-1,878,863.89$ & 20.66 \\
\hline Poly C-Si & $1,763,479.07-1,959,714.85$ & 21.25 & $1,725,487.3-1,853,075.56$ & 20.43 \\
\hline $\mathrm{a}-\mathrm{Si}$ & $1,801,277.36-2,001,719.24$ & 21.71 & $1,762,471.27-1,962,879.80$ & 21.26 \\
\hline CIGS & $1,776,001.66-1,973,630.92$ & 21.4 & $1,737,740.1-1,937,071.83$ & 20.97 \\
\hline CdTe & $1,778,776.55-1,976,714.59$ & 21.44 & $1,740,455.21-1,944,358.05$ & 21.03 \\
\hline \multirow[t]{2}{*}{ Type of cell } & \multicolumn{2}{|l|}{ Zone 7} & \multicolumn{2}{|l|}{ Zone 8} \\
\hline & Yearly generation (kWh) & Average CUF & Yearly generation $(\mathrm{kWh})$ & Average CUF \\
\hline \multicolumn{5}{|l|}{ Zone-7 and 8} \\
\hline Mono C-Si & $1,479,352.94-1,732,409.73$ & 18.33 & $1,457,001-1,713,706.25$ & 18.10 \\
\hline Poly C-Si & $1,459,048.1-1,703,569.16$ & 18.05 & $1,432,745.34-1,685,177.05$ & 17.80 \\
\hline $\mathrm{a}-\mathrm{Si}$ & $1,545,504.19-1,841,548.78$ & 19.33 & $1,548,789.74-1,821,667.01$ & 19.24 \\
\hline CIGS & $1,525,183.87-1,818,220.31$ & 19.08 & $1,529,169.9-1,798,590.40$ & 18.99 \\
\hline $\mathrm{CdTe}$ & $1,530,920.8-1,827,228.05$ & 19.17 & $1,536,745.64-1,807,500.89$ & 19.09 \\
\hline \multirow[t]{2}{*}{ Type of cell } & \multicolumn{2}{|l|}{ Zone 9} & \multicolumn{2}{|l|}{ Zone 10} \\
\hline & Yearly generation (kWh) & Average CUF & Yearly generation $(\mathrm{kWh})$ & Average CUF \\
\hline \multicolumn{5}{|l|}{ Zone-9 and 10} \\
\hline Mono C-Si & $1,954,055.02-2,251,295.31$ & 24.00 & $1,932,728.36-2,017,438.51$ & 22.55 \\
\hline Poly C-Si & $1,937,250.14-2,231,934.17$ & 23.80 & 1,916,106.9-1,989,748.18 & 22.29 \\
\hline $\mathrm{a}-\mathrm{Si}$ & $1,978,773.03-2,279,773.29$ & 24.31 & $1,957,176.60-2,107,650.98$ & 23.20 \\
\hline CIGS & $1,951,006.69-2,247,783.29$ & 23.97 & $1,929,713.3-2,079,939.55$ & 22.89 \\
\hline CdTe & $1,954,055.02-2,251,295.31$ & 24.00 & $1,932,728.36-2,087,763.16$ & 22.95 \\
\hline
\end{tabular}


Table 5 continued

\begin{tabular}{|c|c|c|c|c|}
\hline \multirow[t]{2}{*}{ Type of cell } & \multicolumn{2}{|l|}{ Zone 11} & \multicolumn{2}{|l|}{ Zone 12} \\
\hline & Yearly generation (kWh) & Average CUF & Yearly generation (kWh) & Average CUF \\
\hline \multicolumn{5}{|c|}{ Zone-11 and 12} \\
\hline Mono C-Si & $1,547,875.49-1,864,503.05$ & 19.48 & $1,523,953.61-1,864,503.05$ & 19.34 \\
\hline Poly C-Si & $1,526,630.14-1,833,463.43$ & 19.18 & $1,498,583.35-1,833,463.43$ & 19.02 \\
\hline $\mathrm{a}-\mathrm{Si}$ & $1,617,090.82-1,981,963.76$ & 20.54 & $1,619,960.26-1,981,963.76$ & 20.56 \\
\hline CIGS & $1,595,829.28-1,956,856.54$ & 20.28 & $1,599,438.84-1,956,856.54$ & 20.30 \\
\hline CdTe & $1,601,831.94-1,966,551.11$ & 20.37 & $1,607,362.70-1,966,551.11$ & 20.40 \\
\hline \multirow[t]{2}{*}{ Type of cell } & \multicolumn{2}{|l|}{ Zone 13} & \multicolumn{2}{|l|}{ Zone 14} \\
\hline & Yearly generation (kWh) & Average CUF & Yearly generation $(\mathrm{kWh})$ & Average CUF \\
\hline \multicolumn{5}{|c|}{ Zone-13 and 14} \\
\hline Mono C-Si & $2,181,317.21-21,847,68.13$ & 24.92 & $1,701,133.52-1,993,089.47$ & 21.08 \\
\hline Poly C-Si & $2,154,781.12-2,162,557.89$ & 24.64 & $1,677,784.63-1,959,909.18$ & 20.76 \\
\hline $\mathrm{a}-\mathrm{Si}$ & $2,208,910.00-2,282,462.97$ & 25.64 & $1,777,201.98-2,118,650.92$ & 22.24 \\
\hline CIGS & $2,177,914.36-2,252,453.11$ & 25.29 & $1,753,835.30-2,091,812.16$ & 21.95 \\
\hline CdTe & $2,181,317.21-2,260,925.63$ & 25.36 & $1,760,432.29-2,102,175.32$ & 22.05 \\
\hline Type of cell & Yearly generation & & $\begin{array}{l}\text { Average } \\
\text { CUF }\end{array}$ & \\
\hline \multicolumn{5}{|l|}{ Zone-15 } \\
\hline Mono C-Si & \multicolumn{2}{|c|}{$1,976,723.92-1,629,540.59$} & \multicolumn{2}{|l|}{20.58} \\
\hline Poly C-Si & \multicolumn{2}{|c|}{$1,602,412.55-1,943,816.09$} & \multicolumn{2}{|l|}{20.24} \\
\hline $\mathrm{a}-\mathrm{Si}$ & \multicolumn{2}{|c|}{$1,732,199.05-2,101,254.37$} & \multicolumn{2}{|l|}{21.88} \\
\hline CIGS & \multicolumn{2}{|c|}{$1,710,255.81-2,074,635.99$} & \multicolumn{2}{|l|}{21.60} \\
\hline CdTe & \multicolumn{2}{|c|}{$1,718,728.68-2,084,914.06$} & \multicolumn{2}{|l|}{21.71} \\
\hline
\end{tabular}

Table 6 Validation table of mathematical model

\begin{tabular}{|c|c|c|c|c|c|c|c|}
\hline $\begin{array}{l}\text { Plant } \\
\text { no. }\end{array}$ & Technology & $\begin{array}{l}\text { Actual generated } \\
\text { energy }(\mathrm{kWh} / \mathrm{MW})\end{array}$ & $\begin{array}{l}\text { Absolute \%error in } \\
\text { energy prediction }\end{array}$ & $\begin{array}{l}\text { Predicted energy } \\
\text { generation }(\mathrm{kWh} / \\
\text { MW) }\end{array}$ & $\begin{array}{l}\text { Actual } \\
\text { CUF }(\%)\end{array}$ & $\begin{array}{l}\text { Predicted } \\
\text { CUF }(\%)\end{array}$ & $\begin{array}{l}\text { Absolute \%error in } \\
\text { CUF prediction }\end{array}$ \\
\hline Plant 1 & Multi C-Si & $1,690,376.2$ & 4.67 & $1,602,413-1,943,816$ & 19.41 & $18.29-22.19$ & 4.10 \\
\hline Plant 2 & & $1,774,504$ & 0.08 & & 20.32 & & 0.40 \\
\hline Plant 3 & & $1,939,950.4$ & 9.41 & & 22.18 & & 9.58 \\
\hline Plant 4 & & $1,909,264.2$ & 7.68 & & 21.92 & & 8.30 \\
\hline Plant 5 & & $1,693,517.8$ & 4.49 & & 19.44 & & 3.95 \\
\hline Plant 6 & & $1,940,648$ & 9.45 & & 22.19 & & 9.63 \\
\hline Plant 7 & & $1,955,562$ & 10.29 & & 22.17 & & 9.54 \\
\hline Plant 8 & & $1,794,901.8$ & 1.23 & & 20.80 & & 2.77 \\
\hline Plant 9 & & $1,882,971.8$ & 6.20 & & 21.72 & & 7.31 \\
\hline Plant 10 & $\mathrm{a}-\mathrm{Si}$ & $1,853,285.2$ & 3.31 & $1,732,199-2,101,254$ & 21.54 & $19.77-23.99$ & 1.55 \\
\hline Plant 11 & CdTe & $1,817,119.8$ & 4.45 & $1,718,729-2,084,914$ & 21.43 & $19.62-23.80$ & 1.29 \\
\hline Plant 12 & & $1,807,359$ & 4.97 & & 20.82 & & 4.10 \\
\hline Plant 13 & & $2,024,909.2$ & 6.47 & & 23.80 & & 9.63 \\
\hline Plant 14 & CIS & $1,795,320$ & 5.13 & $1,710,256-2,074,636$ & 21.44 & $19.52-23.68$ & 0.74 \\
\hline Plant 15 & & $1,864,970$ & 1.45 & & 21.75 & & 0.69 \\
\hline
\end{tabular}


Table 6 shows that actual generation and CUF of all the selected PV plants are in the range of predicted value got through mathematical model. Percentage errors in prediction of energy generation and CUF for all the fifteen PV plants are also calculated. Results indicate that maximum percentage error in prediction of annual energy generation is $10.29 \%$ where as minimum is with a value of $0.08 \%$ for plant 2 . So, mathematical model is in good correlation with the actual field output and CUF of PV power plants.

\section{Conclusion}

The mathematical model used for technical feasibility study of PV power plant is validated collecting the actual field output data of $15 \mathrm{PV}$ power plants of different technologies. Findings of the proposed work are tabulated below:

- For multi-C-Si predicted energy generation and CUF is $1,602,413-1,943,816 \mathrm{kWh} / \mathrm{MW}$ and $18.29-22.19 \%$, whereas actual field generation and CUF are 1,690,376.2-1,955,562 kWh/MW and 19.41-22.19\%, respectively. So actual field output is in the range of prediction.

- For a-Si actual field energy generation and CUF are $1,853,285.2 \mathrm{kWh} / \mathrm{MW}$ and $21.54 \%$, respectively. These values are also within the prediction range.

- Actual energy generation and CUF of CdTe-based PV plants are 1,807,359-2,024,909.2 kWh/MW and $20.82-23.80 \%$, respectively, which is also within the range of prediction.

- CIS-based PV power plants export annually 1795320-1,864,970 kWh/MW energy to the grid which is within the prediction range.

So, technical feasibility model is in good correlation with the actual field output of PV power plants. This validation would be more trustable if more numbers of a-Si, CdTe and CIGS-based PV power plants data can be compared with predicted data. Due to unavailability of more practical data and as PV plants are not installed in all climatic zones of India till now, further validation in all climatic zones is not possible now. The ministry has future plans for installation of PV power plants all over India; therefore, much better validation of the work will be possible.

Open Access This article is distributed under the terms of the Creative Commons Attribution 4.0 International License (http://crea tivecommons.org/licenses/by/4.0/), which permits unrestricted use, distribution, and reproduction in any medium, provided you give appropriate credit to the original author(s) and the source, provide a link to the Creative Commons license, and indicate if changes were made.

\section{References}

1. Chakraborty, S., Sadhu, P.K., Pal, N.: New location selection criterions for solar PV power plant. Int J Renew Energy Res 4(4), 1020-1030 (2014)

2. Goh, T.N., Tan, K.J.: Stochastic modeling and forecasting of solar radiation data. Sol Energy 19, 755-757 (1977)

3. Chakraborty, S., Sadhu, P.K., Pal, N.: Technical mapping of solar PV for ISM-an approach toward green campus. Energy Sci Eng 3(3), 196-206 (2015)

4. Sfetsos, A., Coonick, A.: Univariate and multivariate forecasting of hourly solar radiation with artificial intelligence techniques. Sol Energy 68(2), 169-178 (2000)

5. Das, S., Sadhu, P.K., Chakraborty, S., Saha, M., Sadhu, M.: Life cycle economic analysis of stand-alone solar PV system in India-a relative study. World J Eng 12(1), 37-44 (2015)

6. Hontoria, L., Aguilera, J., Zuria, P.: Generation of hourly irradiation synthetic series using the neural network multilayer perception. Sol Energy 72, 441-446 (2002)

7. Shuanghua, C., Jiacong, C.: Forecast of solar irradiance using recurrent neural networks combined with wavelet analysis. Appl Therm Eng 25, 161-172 (2005)

8. Mellit, A., Benghanem, M., Kalogirou, S.A.: An adaptive wavelet network model for forecasting daily total solar radiation. Appl Energy 83, 705-722 (2006)

9. Hocaoglu, F.O., Gerek, O.N., Kurban, M.: Hourly solar radiation forecasting using optimal coefficient 2-D linear filters and feedforward neural networks. Sol Energy 82(8), 714-726 (2008)

10. Mellit, A., Kalogirou, S.A., Shaari, S., Salhi, H., Arab, A.H.: Methodology for predicting sequences of mean monthly clearness index and daily solar radiation data in remote areas: application for sizing a stand-alone PV system. Renew Energy 33, $1570-1590$ (2008)

11. Cao, J., Lin, X.: Study of hourly and daily solar irradiation forecast using diagonal recurrent wavelet neural networks. Energy Convers Manag 49(6), 1396-1406 (2008)

12. Reikard, G.: Prediction solar radiation at high resolutions: a comparison of time series forecasts. Sol Energy 83, 342-349 (2009)

13. Kerr, M.J., Cuevas, A.: Generalized analysis of the illumination intensity vs. open-circuit voltage of PV modules. Sol Energy 76, 263-267 (2003)

14. Radziemska, E., Klugmann, E.: Thermally-affected parameters of the current-voltage characteristics of silicon photocell. Energ Convers Manage 43, 1889-1900 (2002)

15. Van Dyk, E.E., et al.: Temperature-dependent of performance of crystalline silicon photovoltaic modules. S Afr J Sci 96, 198-200 (2000)

16. Nishioka, K., et al.: Field-test analysis of PV-system-output characteristics focusing on module temperature. Sol Energy Mater PV Module 75, 665-671 (2003)

17. Pau, C.T.: Output energy of a photovoltaic module mounted on a single axis tracking system. Appl Energy 86, 2071-2078 (2009)

18. Mayar, D., Heidenreich M.: Performance Analysis of Stand Alone PV Systems from a Rational Use of Energy Point of View. French Agency for Environment and Energy Management, France (2003)

19. Charles, Iskander, Edward, Scerri: Performance and cost evaluation of a standalone photovoltaic system in Malta. Renew Energy 8, 437-440 (1996)

20. García-Valverde, R., Miguel, C., Martínez-Béjar, R., Urbina, A.: Life cycle assessment study of a $4.2 \mathrm{kWp}$ stand-alone photovoltaic system. Sol Energy 83, 1434-1445 (2009)

21. Lesourd, J.B.: Solar photovoltaic systems: the economics of a renewable energy resource. Environ Model Softw 16, 147-156 (2001) 
22. Kannan, R., Leong, K.C., Osman, R., Ho, H.K., Tso, C.P.: Life cycle assessment study of solar PV systems: an example of a 2.7 $\mathrm{kWp}$ distributed solar PV system in Singapore. Sol Energy 80, 555-563 (2006)

23. Bhuiyan, M.M.H., Ali Asgar, M., Mazumdar, R.K., Hussain, M.: Economic evaluation of standalone residential photovoltaic power system in Bangladesh. Renew Energy 15, 403-410 (2000)

24. Evans, D.L.: Simplified method for predicting photovoltaic array output. Sol Energy 27, 555-560 (1981)

25. Mondol, J.D., Yohanis, Y.G., Smyth, M., Norton, B.: Long-term validated simulation of a building integrated photovoltaic system. Sol Energy 78, 163-176 (2005)

26. Hove, T.: A method for predicting long-term average performance of photovoltaic systems. Renew Energy 21, 207-229 (2000)

27. Stamenic, L., Smiley, E., Karim, K.: Low light conditions modelling for building integrated photovoltaic (BIPV) systems. Sol Energy 77, 37-45 (2004)

28. Jones, A.D., Underwood, C.P.: A modelling method for buildingintegrated photovoltaic power supply. Building Serv Eng Tes Technol 23, 167-177 (2002)

29. Ayompe, L.M., Duffy, A., McCormack, S.J., Conlon, M.: Validated real-time energy models for small-scale grid connected PVsystems. Energy 35(10), 4086-4091 (2010)

30. Joyce, A., Rodrigues, C., Manso, R.: Modelling a PV system. Renew Energy 22(1), 275-280 (2001)

31. De Soto, W., Klein, S.A., Beckman, W.A.: Improvement and validation of a model for photovoltaic array performance. Sol Energy 80, 78-88 (2006)

32. Celik, A.N., Acikgoz, N.: Modelling and experimental verification of the operating current of mono-crystalline photovoltaic modules using four- and five parameter models. Appl Energy 84(1), 1-15 (2007)

33. Zhou, W., Yang, H., Fang, Z.: A novel model for photovoltaic array performance prediction. Appl Energy 84(12), 1187-1198 (2007)

34. Cameron C, Boyson WE, Riley DM. Comparison of PV system performance model predictions with measured PV system performance. In: IEEE Photovoltaic Specialists Conference, pp. 33, $1-6(2008)$

35. Ashraf, I., Chandra, A.: Artificial neural network based models for forecasting electricity generation of grid connected solar PV power plant. Int J Global Energy 21, 119-130 (2004)

36. Sulaiman, S.I., Abdul Rahman, T.K., Musirin, I., Shaari, S.: Performance analysis of evolutionary ANN for output prediction of a grid-connected photovoltaic system. Int J Electr Comput Eng 5(4), 244-249 (2010)

37. AI-Ismaily, H.A., Probert, D.: Photovoltaic electricity prospects in Oman. Appl Energy. 1998;59:97-124

38. Joyce, A., Rodrigues, C., Manso, R.: Modelling a PV system. Renew Energy 22(1), 275-280 (2001)

39. Santana-Rodŕiguez, G., et al.: Evaluation of a grid-connected photovoltaic system and in situ characterization of photovoltaic modules under the environmental conditions of Mexico city. Rev Mex Fis 59(2), 88-94 (2013)

40. Ronak, D., et al.: Predicting the performance of amorphous and crystalline silicon based photovoltaic solar thermal collectors. Energy Convers Manag 52, 1741-1747 (2011)

41. Adiyabat, A., et al.: Evaluation of solar energy potential and PV module performance in the Gobi Desert of Mongolia. Prog. Photovoltaics Res Appl 14(6), 553-566 (2006)

42. Duong M et al.: Hybrid model for hourly forecast of photovoltaic and wind power. In: Proceedings of FUZZ-IEEE (2013)

43. Dolara, A., Leva, S., Manzolini, G.: Comparison of different physical models for PV power output prediction. Solar Energy 119, 83-99 (2015)

44. Dolara, A., Grimaccia, F., Leva, S., Mussetta, M., Ogliari, E.: A physical hybrid artificial neural network for short term forecasting of PV plant power output. Energies 8(2), 1138-1153 (2015)

45. Leva, S., Dolara, A., Grimaccia, F., Mussetta, M., Ogliari, E.: Analysis and validation of 24 hours ahead neural network forecasting of photovoltaic output power. Math Comput Simul 131, 88-100 (2017)

46. Ross, R.: Flat-Plate Photovoltaic Array Design Optimization. In: 14th IEEE Photovoltaic Specialists Conference, pp. 1126-1132. San Diego, New York (1980)

47. Skoplaki, E., Palyvos, J.: On the temperature dependence of photovoltaic module electrical performance: a review of efficiency/power correlations. Sol. Energy 83(5), 614-624 (2009). doi:10.1016/j.solener.2008.10.008

48. Garcia, M.C.A., Balenzategui, J.L.: Estimation of photovoltaic module yearly temperature and performance based on nominal operation cell temperature calculations. Renew. Energy 29(12), 1997-2010 (2004). doi:10.1016/j.renene.2004.03.010

49. Malik, A., Damit, S.: Outdoor testing of single crystal silicon solar cells. Renew. Energy 28(9), 1433-1445 (2003). doi:10. 1016/s0960-1481(02)00255-0

50. http://nvvn.co.in/. Accessed June 2015 